\title{
A Review on Embryonic Development of Inland Fishes of Bangladesh
}

\author{
Md. Borhan Uddin Ahmed ${ }^{1}$, Jobayda Sifat ${ }^{1}$, Md. Fazla Rabbi ${ }^{1}$, Md. Ashraful Islam ${ }^{1}$, H.M. Al Kabid Rafin ${ }^{1}$ \& \\ Md. Kamal Uddin ${ }^{1}$ \\ ${ }^{1}$ Department of Fisheries Biology and Genetics, Bangladesh Agricultural University, Memensingh-2202, \\ Bangladesh \\ Correspondence: Md. Borhan Uddin Ahmed, Department of Fisheries Biology \& Genetics, Bangladesh \\ Agricultural University, Mymensingh-2202, Bangladesh. E-mail: mbuasiam@gmail.com, \\ borhan.fbg15@bau.edu.bd
}

Received: January 5, 2020 Accepted: February 14, 2020 Online Published: February 18, 2020

\begin{abstract}
The early developmental pattern of inland fishes of Bangladesh are not well studied though it has a great importance in fisheries and aquaculture sector. The embryonic study provides interesting information on further growth and health of the fish and considered as an essential component for optimization of fish seed production by natural and induced breeding. Therefore, the current review work has been undertaken to provide a detail information on embryonic development of important inland fishes of Bangladesh. Information was collected from published scientific papers, un-published Masters and $\mathrm{PhD}$ dissertations from universities, popular articles and other published and grey literature. Diameters of unfertilized egg of the reviewed fish species were found to be 0.5 to $1.3 \mathrm{~mm}$ and fertilized egg were 0.49 to $1.6 \mathrm{~mm}$. Shapes of the egg were also variable from species to species. There is little information available on egg activation and egg micropyle of fish species of Bangladesh. The fertilization rate of different fishes ranged from $40.1 \%$ to $93.9 \%$. There are different stages of early development in different species and time needs to complete the stages also vary. The timing of post hatching development by metamorphosis was found to vary based on the fish species from several days to weeks. Different factors like temperature, photoperiod, DO, seasonality and presence of chemicals in water were found to affect the early development of fish. The review included eighteen inland fishes and unearthed useful insights of their embryonic development and influence of different factors. As we expect, the outcome of the study would provide a baseline and would be very useful in conducting further research on the embryology of indigenous fishes of Bangladesh.
\end{abstract}

Keyword: Fish embryo, ontogenic development, early life stage, hatching, larvae

\section{Introduction}

Bangladesh is a land with massive potential water bodies with a wide diversity of fishes. During several decades' fishes of Bangladesh has declining due to various natural causes. Different man-made activities are also influencing the process. IUCN (2015) reported that 64 fish species are threatened which comprises 9 Critically Endangered, 30 Endangered and 25 Vulnerable fish species. Therefore, the conservation of this fishes is considerably important. The knowledge on early developmental pattern is essential for establishment of proper conservation measure. However, there is a very little knowledge available about the early embryonic and larval development of fishes of Bangladesh. Embryonic development is a complex process in which cellular differentiation and proliferation occur simultaneously at different rate (Hall, 2003). Changes in the pattern of the entire structure of an organ or of specific organ in relation to the environment are decisive for evaluating the developmental pattern of a species. Information on early life history is an essential requirement for optimization of mass seed production, culture and management of fishes. Embryonic development and larval development providing remarkable information in itself are imperative and consequential to the successful rearing of larvae for large scale seed production. Therefore, it is indispensable to conduct study to characterize different embryonic and larval stages of fish. In addition, embryonic developmental stages of fish life are also used in various investigational studies; especially in aquaculture as well as toxicological studies (Rahman et al., 2009).

\subsection{Fish Embryo}

Embryo is the earliest developing stages of fish from the time when the fertilized egg starts to divide, while it is continued within the egg until hatching. The embryo goes through several complex stages before hatching. Embryo is the result of fusion of male and female gamete and the first stage of life in fish as well as other animals (Langeland \& Kimmel, 1997). 


\subsection{Gametogenesis}

The process of gamete formation in the sexually reproducing animals is gametogenesis. The male gamete is known as spermatozoon or sperm, and the female gamete is known as ovum or egg. Fish produce gametes directly through meiosis in organs called gonads (testis in males and ovaries in females). Gametogenesis are of two types; spermatogenesis and oogenesis (Andrade et al., 2001).

\subsubsection{Spermatogenesis}

Spermatogenesis involves two distinct process known as formation of the spermatids and Spermiogenesis (Sharma et al., 2018). The primordial germinal cells called spermatogonia undergoes repeated mitotic divisions to maintain a supply of cells for the production of sperm. After meiosis primary spermatocytes form secondary spermatocytes; after the second meiotic division, they are spermatids (Avidor-Reiss et al., 2015). The metamorphosis or differentiation of the spermatids into the sperm is called spermiogenesis. Spermiogenesis is characterized by changes in the nucleus, acrosome formation and Centrioles (Avidor-Reiss et al., 2015).

\subsubsection{Oogenesis}

The primordial germinal cells divide repeatedly to form the oogonia which multiply by the mitotic divisions and form the primary oocytes and pass through the growth phase. In the primary oocyte, large amount of fats and proteins become accumulated in the form of yolk and due to its heavy weight, it is concentrated towards the lower portion of the egg (forming vegetal pole). After this process cytoplasm of egg divides unequally forming three polar body and one egg (Lubzens et al., 2010).

\subsection{Different Embryonic Developmental Stages of Fishes}

\subsubsection{Fertilized Eggs}

Prior to fertilization, the egg is in a quiescent state, arrested in metaphase of the second meiotic division. Upon binding of a sperm, the egg rapidly undergoes a number of metabolic and physical changes. The yolk is usually translucent and yellowish in color; the oil droplets are unchanged (Kinsey et al., 2007). Aerobic respiration increases in the egg (Nakano, 1953). Enzyme systems become activated. In most animals, a burst of protein synthesis begins and the nucleus undergoes the second division of meiosis after fertilization.

\subsubsection{Cleavage}

The zygote experiences a quick cell cycles with no significant growth, producing a cluster of cells within few minutes of fertilization is called cleavage (Sperber, 1995). Cleavage is basically occurring in the blastodisc region of the animal pole of the eggs which further converts into embryo (Fukazawa et al., 2010). After several successive cell division, the egg forms a thick layer of cell known as germ ring and is made up of superficial layer, ectoderm, endoderm mesoderm (Lee et al., 2004). A dorsal-ventral axis forms at that time that may be referred as prenotochord from which a neural plate is formed. Cells of the neural plate fold to form the neural groove and the surrounding neural folds which fuse, forming a hollow neural tube (Forgacs \& Newman, 2005).

\subsubsection{Morula, Blastula and Gastrula}

A series of cleavage of zygote forms a solid ball of cell is called morula which occurs within few hours of fertilization. Soon after development of the 8-cell or 16-cell embryo (depending on the species), the blastomeres begin to form mulberry-shaped mass of cells called a morula. This change in shape of the embryo is called compaction (Forgacs \& Newman, 2005). This compaction leads to form a hollow sphere called blastula, surrounding by a hollow blastocoel (Forgacs \& Newman, 2005). The blastula enhances gastrula formation in which embryo form germ layers (Gilbert, 2010). Gastrula is a dramatic rearrangement of the cells of the blastula. Initially blastoderm cells move outwardly to intercalate with the more superficial cells which leads to the formation of gastrula (Warga \& Kimmel, 1990). At this stage the yolk syncytial layer starts expansion around the yolk cell (Trinkaus, 1984). By the end of gastrulation, embryonic cells have rearranged into three layers' ectoderm, mesoderm and endoderm.

\subsection{Importance of Embryonic Developmental Study of Fishes of Bangladesh}

Different organs of fish develop in different embryonic stage. Knowledge about the timing of different organ development of fish can be extended by embryonic study. Knowledge on cleavage pattern of Bangladeshi fish can be achieved by embryonic study. Embryonic study can be helpful to optimize survival and growth rate of fish larvae in our country. Embryonic development besides, providing interesting information are imperative and substantial to the successful rearing of larvae for large scale seed production of any species and thus important for hatchery operators. 


\subsection{Factors Affecting Embryonic Development}

A wide-ranging literature is present on the problem of the effect employed by some environmental factors upon the embryonic stage in fishes. These factors are like temperature, salinity, light, and some mechanical factors. Among this factors temperature is the most prominent factor as it is well known, the rate of the embryonic development of a given species is directly related to the temperature. Salinity is another important factor that affect the embryonic development of fishes. Every fish species has a tolerance limit of salinity beyond which in cannot survive. Light is not always controls the development of fish embryo. However, it has been shown in case of some species e.g. some salmonids, light usually has a negative impact on the early development of embryo (Eisler, 1957). Rather than these factors, some mechanical factors like pressure, shock etc. can sometime influence the embryonic development of fishes (Ciechomski, 1964).

\subsection{Justification and Objectives of the Study}

The embryonic and larval stages are considered very sensitive indicators of environmental disturbances (Marimuthu and Haniffa 2007). They are also indispensable in the study on ontogeny and phylogeny of their families (Legendre and Teugels 1991; Verreth et al., 1992). In addition, such studies on the embryonic development of any cultivable species can be useful in directing the husbandry efforts of fish farmer. In Bangladesh the embryonic study of fish has been not yet gained so much attention though it has a huge potential in the sector of fish and fisheries. The current review work is therefore has been undertaken to provide a details knowledge about the embryonic development of fishes of Bangladesh, its current status and future research importance on embryonic development of fishes of Bangladesh.

\section{Materials and Methods}

\subsection{Literature Collection and Review}

Literature were collected from different journals, published paper, Magazines related to fish and fisheries. Unpublished research from masters and $\mathrm{PhD}$ research were also considered. Personal communication with the experts on the field of fish embryology were done for collection of some information. The fish species under this review are given in Table 1.

Table 1. Fish species under review.

\begin{tabular}{|c|c|c|c|}
\hline Local name & Scientific name & Family & Author \\
\hline Rui & Labeo rohita & Cyprinidae & Das et al., 2006 \\
\hline Catla & Gibelion catla & Cyprinidae & Tumbahangfe et al., 2014 \\
\hline Mrigel & Cirrhinus cirrhosus & Cyprinidae & Chakraborty and Murty, 1972 \\
\hline Desi Sarputi & Puntius sarana & Cyprinidae & Chakraborty et al., 2007 \\
\hline Bata & Labeo bata & Cyprinidae & Hossain et al, 2007; Miah et al., 2009 \\
\hline Silver berb & Barbodes gonionotus & Cyprinidae & Basak et al., 2014 \\
\hline Tara Baim & $\begin{array}{l}\text { Macrognathus } \\
\text { aculeatus }\end{array}$ & Mastacembelidae & Farid et al., 2008 \\
\hline Guchi baim & $\begin{array}{l}\text { Mastacembelus } \\
\text { pancalus }\end{array}$ & Mastacembelidae & $\begin{array}{l}\text { Hasan, M.R. et al., 2016; Rahman et al., } \\
2009\end{array}$ \\
\hline Shol & Channa striatus & Channidae & $\begin{array}{l}\text { Roy et al, 2016; Marimuthu \& Haniffa, } \\
2007\end{array}$ \\
\hline Taki & Channa punctatus & Channidae & Banerji, 1975 \\
\hline Tengra & Mystus cavasius & Bagridae & Rahman et al., 2004 \\
\hline Rita & Rita rita & Bagridae & Molla et al., 2008; Mollah et al., 2011 \\
\hline Pabda & Ompok pabo & Siluridae & $\begin{array}{l}\text { Purkayastha et al., 2012; Sarma et al., } \\
2012\end{array}$ \\
\hline Kani Pabda & Ompok bimaculatus & Siluridae & Raizada et al., 2013 \\
\hline Pangas & Pangasius pangasius & Pangasiidae & $\begin{array}{l}\text { Khan \& Mollah, 2004; Ferosekhan et al., } \\
2015\end{array}$ \\
\hline Local & Anabas testudineus & Ana & Karim et al., (2012) \\
\hline Gutum & $\begin{array}{l}\text { Lepidocephalicthys } \\
\text { guntea }\end{array}$ & Cobitidae & Sayeed et al, 2009 \\
\hline Meni, Bheda & Nandus nandus & Nandi & Pal, et al., 2003; Das et al., 2002 \\
\hline Shing & Heteropneustes fossilis & Heteropneustidae & Puvaneswari et al., 2009; Nesa et al., 2017 \\
\hline
\end{tabular}




\subsection{Data Analyses, Tabular and Graphical Representation}

All collected data were subjected in computer software MS Excel v2016 for analysis and graphical representation.

\section{Results and Discussion}

\subsection{Fertilization}

The egg and spermatozoa are the main component for fertilization. The eggs and spermatozoa of many fish have an extremely short functional life after spawning. Marimuthu \& Haniffa, (2007) showed in case of Channa striatus fertilized egg were free floating, spherical, non-adhesive translucent and yellow in color. In case of Rita rita, Mollah et al., (2011) reported the same result but it was demersal and brownish in color. They reported a redish spot in the fertilized egg which indicates the blastodisc. Same blastodisc has been reported in case of Macrognathus aculeatus, Labeo bata, Anabas testudineus, Nandus nandus, Heteropneustes fossilis, Mystus cavasius, by Farid et al., (2008); Miah et al., (2009); Karim et al., (2012); Das et al., (2002); Nesa et al., (2017); Rahman et al., (2004). The diameter of fertilized and unfertilized eggs is varying in species to species. Fertilization rate, hatching rate, diameter of fertilized and unfertilized egg of different fish species are given in the Table 2.

The fertilization rate of different fish species is different. Fertilization rate are also season dependent in case of many species. Fertilization rate also differs depending on the natural or striping.

Table 2. Fertilization rate, hatching rate and egg diameter of different inland fishes of Bangladesh

\begin{tabular}{|c|c|c|c|c|c|}
\hline \multirow[t]{2}{*}{ Species name } & \multirow{2}{*}{$\begin{array}{l}\text { Highest } \\
\text { fertilization } \\
\text { rate }(\%)\end{array}$} & \multirow{2}{*}{$\begin{array}{l}\text { Highest } \\
\text { hatching } \\
\text { rate (\%) }\end{array}$} & \multicolumn{2}{|c|}{ Egg diameter } & \multirow[t]{2}{*}{ Author } \\
\hline & & & $\begin{array}{l}\text { Unfertiliz } \\
\text { ed }(\mathrm{mm})\end{array}$ & $\begin{array}{l}\text { Fertilized } \\
(\mathrm{mm})\end{array}$ & \\
\hline Catla Catla & 93.9 & 90.98 & - & 4.5 & Tumbahangfe et al., 2014 \\
\hline Labeo bata & 92.33 & 88.33 & $0.7 \pm 0.01$ & $0.8 \pm 0.01$ & $\begin{array}{l}\text { Hossain et al, 2007; Miah et } \\
\text { al., } 2009\end{array}$ \\
\hline Mystus cavasius & - & - & - & $\begin{array}{ll}0 . & 49- \\
0.51 & \\
\end{array}$ & Rahman et al., 2004 \\
\hline Rita rita & $71.66 \pm 7.64$ & $\begin{array}{l}48.33 \pm 7.6 \\
4\end{array}$ & 1.0 to 1.3 & $1.3-1.6$ & $\begin{array}{l}\text { Molla et al., 2008; Mollah } \\
\text { et al., } 2011\end{array}$ \\
\hline $\begin{array}{l}\text { Mastacembelus } \\
\text { pancalus }\end{array}$ & $75.23 \pm 1.13$ & $\begin{array}{l}55.12 \pm \\
1.07 \\
\end{array}$ & $0.50 \pm 0.00$ & $\begin{array}{l}0.70 \pm 0.0 \\
2\end{array}$ & $\begin{array}{l}\text { Hasan, et al., 2016; } \\
\text { Rahman et al., 2009 }\end{array}$ \\
\hline $\begin{array}{l}\text { Macrognathus } \\
\text { aculeatus }\end{array}$ & - & - & $0.7 \pm 0.11$ & $0.8 \pm 0.11$ & Farid et al., 2008 \\
\hline Ompok pabo & 75.5 & 60.5 & $0.99-1.1$ & $1.0-1.3$ & $\begin{array}{l}\text { Purkayastha et al., 2012; } \\
\text { Sarma et al., } 2012\end{array}$ \\
\hline Ompok bimaculatus & $75-90$ & $80-90$ & - & - & Raizada et al., 2013 \\
\hline Heteropneustes fossilis & $62.33 \pm 4.51$ & $\begin{array}{l}41.33 \pm 5.6 \\
9\end{array}$ & $1-1.1$ & $1.3-1.4$ & Nesa et al., 2017 \\
\hline Anabas testudineus & - & - & $0.6 \pm 0.01$ & $0.7 \pm 0.0$ & Karim et al., (2012) \\
\hline $\begin{array}{l}\text { Lepidocephalicthys } \\
\text { guntea }\end{array}$ & $78.60 \pm 3.21$ & $\begin{array}{l}65.49 \pm 5.2 \\
3\end{array}$ & - & - & Sayeed et al, 2009 \\
\hline Nandus nandus & $92 \pm 5 \%$ & $90 \pm 2$ & 0.6 & 0.8 & $\begin{array}{l}\text { Pal, et al., 2003; Das et al., } \\
2002\end{array}$ \\
\hline Pangasius pangasius & $40.1 \pm 3.1$ & $65.0 \pm 2.3$ & $1.09-1.28$ & $1.2-1.45$ & $\begin{array}{l}\text { Khan \& Mollah, 2004; } \\
\text { Ferosekhan et al., 2015 }\end{array}$ \\
\hline Channa striatus & $59.5 \pm 2.50$ & $67.5 \pm 2.50$ & - & $\begin{array}{l}1.20 \\
1.40\end{array}$ & $\begin{array}{l}\text { Roy et al, 2016; Marimuthu } \\
\text { \& Haniffa, } 2007\end{array}$ \\
\hline
\end{tabular}

\subsubsection{Egg Activation}

The event of egg activation is thought to be the result from the introduction of protein or other component from the sperm plasma to the egg. The existence of some factors which are capable of triggering egg for activation has been reported by Coward et al., (2003). The majority of the evidence to date indicates that the critical sperm component is a phospholipase isoform (phospholipase zeta) (Cox et al., 2002; Saunders et al., 2002). One of the exceptions of this was found in the study by Lee et al. (1999), which described the apparently normal activation 
of zebrafish egg in the absence of sperm. This may be defined as parthenogenic activation egg. In general, some morphological changes occur during fertilization while the egg is being activated. According to Kinsey et al. (2007), some morphological changes occur in the fish egg at fertilization like progressive disintegration of cortical alveoli, reduction in volume, transformation of the chorion, expulsion of second polar body, bipolar differentiation. Kusa (1953) says that the first observable change after fertilization involves the outline of the alveolus becoming indistinct. The alveolus then disappears. Till date no researches were recorded on egg activation of fishes of Bangladesh. Details study is needed for the proper knowledge about the activation of fish egg of Bangladesh.

\subsubsection{Micropyle}

There is no significant record of micropyle study of Bangladeshi fish. At the internal aperture of the micropylar canal a site of sperm attachment was found on the egg membrane (Kudo, 1982), recognized as a gentle cytoplasmic swelling, bearing 19-27 cytoplasmic finger-like projections (Kudo, 1982).

\subsection{Embryonic Developmental Stages and Timing of Development in Different Fish Species}

The timing of development is species specific and also stage specific, that means different developmental stage needs different time for each species. In Bangladesh, the developmental timing for all species is not well known. However, in case of some species, research shows some good findings. A complete chart on the timing of development is shown in the Table 3.

Table 3. Timing of early developmental stages of inland fishes of Bangladesh

\begin{tabular}{|c|c|c|c|c|c|c|c|}
\hline Stages/Species & $\begin{array}{l}\text { Labeo } \\
\text { bata } \\
\text { (Miah } \\
\text { et al., } \\
2009 \text { ) }\end{array}$ & $\begin{array}{l}\text { Ompok } \\
\text { pabo } \\
\text { (Sarma et } \\
\text { al., 2012) }\end{array}$ & $\begin{array}{l}\text { Heteropneustes } \\
\text { Fossilis } \\
\text { (Nesa et al., 2017) }\end{array}$ & $\begin{array}{l}\text { Channa } \\
\text { striatus } \\
\text { (Marimuthu } \\
\text { and Haniffa } \\
\text { 2007) }\end{array}$ & $\begin{array}{l}\text { Macrognathus } \\
\text { aculeatus } \\
\text { (Farid et al. } \\
\text { 2008). }\end{array}$ & $\begin{array}{l}\text { Anabas } \\
\text { testudineus } \\
\text { (Karim et al., } \\
\text { 2012) }\end{array}$ & $\begin{array}{l}\text { Barbodes } \\
\text { gonionotus } \\
\text { (Basak et al., } \\
2014 \text { ) }\end{array}$ \\
\hline Fertilized egg & $00 \mathrm{~min}$ & $00 \mathrm{~min}$ & $00 \mathrm{~min}$ & $00 \mathrm{~min}$ & $00 \mathrm{hrs}$ & $00 \mathrm{hrs}$ & $00 \mathrm{hrs}$ \\
\hline Two cells & $45 \mathrm{~min}$ & $36 \min$ & $20.60 \mathrm{~min}$ & $15-20 \mathrm{~min}$ & - & $1.20 \mathrm{hrs}$ & $0.35 \mathrm{hrs}$ \\
\hline Four cells & $55 \mathrm{~min}$ & $46 \min$ & $39.8 \mathrm{~min}$ & - & - & $1.50 \mathrm{hrs}$ & $0.50 \mathrm{hrs}$ \\
\hline Eight cells & $80 \mathrm{~min}$ & $60 \mathrm{~min}$ & $71.67 \mathrm{~min}$ & - & - & $2.20 \mathrm{hrs}$ & $1.00 \mathrm{hrs}$ \\
\hline Sixteen cells & - & $1.08 \mathrm{hrs}$ & - & $30-50 \mathrm{~min}$ & - & - & $1.20-1.40 \mathrm{hrs}$ \\
\hline $\begin{array}{l}\text { Thirty-two } \\
\text { cells }\end{array}$ & - & - & - & $1.00-1.20 \mathrm{~min}$ & & - & $2.00 \mathrm{hrs}$ \\
\hline Morula & $\begin{array}{l}45-55 \\
\min \end{array}$ & $2.06 \mathrm{hrs}$ & $2.20 \mathrm{hrs}$ & $1.3-2.0 \mathrm{hrs}$ & $5.00 \mathrm{hrs}$ & $5.10 \mathrm{hrs}$ & $3.00 \mathrm{hrs}$ \\
\hline Blastula & $4.30 \mathrm{hrs}$ & $3.30 \mathrm{hrs}$ & $4.15 \mathrm{hrs}$ & $5.00-6.00 \mathrm{hrs}$ & $9.00 \mathrm{hrs}$ & - & $5.00 \mathrm{hrs}$ \\
\hline Gastrulation & $\begin{array}{l}8.30- \\
12 \mathrm{hrs} \\
\end{array}$ & - & $6.35 \mathrm{hrs}$ & $8.00-9.00 \mathrm{hrs}$ & $15.10 \mathrm{hrs}$ & - & $6.15-6.25 \mathrm{hrs}$ \\
\hline $\begin{array}{l}\text { Germinal ring } \\
\text { formed }\end{array}$ & - & - & $5.1 \mathrm{hrs}$ & - & - & $8.20 \mathrm{hrs}$ & - \\
\hline 14 somites & - & - & & - & - & $32.30 \mathrm{hrs}$ & - \\
\hline $16-18$ somites & - & - & & - & -- & $37.30 \mathrm{hrs}$ & - \\
\hline $\begin{array}{l}\text { Yolk plug } \\
\text { stage }\end{array}$ & $16 \mathrm{hrs}$ & $5.00 \mathrm{hrs}$ & $8.25 \mathrm{hrs}$ & - & - & - & -- \\
\hline Organogenesis & $\begin{array}{l}16- \\
18 \mathrm{hrs}\end{array}$ & $14.00 \mathrm{hrs}$ & & - & - & - & - \\
\hline $\begin{array}{l}\text { Just before } \\
\text { hatching }\end{array}$ & $\begin{array}{l}18-20 \\
\text { hrs }\end{array}$ & - & $22.5 \mathrm{hrs}$ & - & $36-40 \mathrm{hrs}$ & $75.20 \mathrm{hrs}$ & - \\
\hline
\end{tabular}




\begin{tabular}{|c|c|c|c|c|c|c|c|}
\hline $\begin{array}{l}\text { Fully active } \\
\text { embryo }\end{array}$ & - & $\begin{array}{l}17.0-18.0 \\
\text { hrs }\end{array}$ & - & & - & - & - \\
\hline $\begin{array}{l}\text { Hatchling } \\
\text { competed }\end{array}$ & $\begin{array}{l}20-21 \\
\text { hrs }\end{array}$ & $20 \mathrm{hrs}$ & $39.5 \mathrm{hrs}$ & $23.30-24.0 \mathrm{hrs}$ & $40 \mathrm{hrs}$ & $80.30 \mathrm{hrs}$ & $\begin{array}{l}13.40-14.00 \\
\text { hrs }\end{array}$ \\
\hline
\end{tabular}

\subsection{Organogenesis and Hatching Temperature}

In organogenesis stage different organs of the fish are formed. In case of Bangladeshi fish, organogenesis is not well studied except only a limited number of species. In an experiment conducted by Farid et al. (2008) reported that organogenesis in case of Tara baim starts almost 11 hours after fertilization. Both tail and head ends were clearly differentiated and the beating heart was visible in this stage. Gills and pectoral fins start to appear. Auditory and optic vesicle develops. These aspects of organogenesis were similar to L. rohita ((Khan, 1943) and C. mrigala (Chakraborty and Murty, 1972). In another study in case of Labeo bata conducted by Miah et al. (2009) concluded that, at the organogenesis stage, appearance of heart rudiment pectoral fin buds and gill rudiment occurs. Notochord becomes visible, auditory and optic vessels developed in 16-18 hours after fertilization. Das et al. (2002) on the other hand, reported that organogenesis occurs 13 hours after fertilization. At this stage both tail and headend were clearly visible and heart beat starts in case of Nandus nandus. Out of this species discussed, there are many commercially important fish species which organogenesis are not well defined in the previous research. However, the pattern of organogenesis is found more or less similar in the species of the country. It may be due to similarity in environmental condition, food supply and geographical location.

Optimum incubation temperature for different fish species is different found. A list of optimum incubation temperature reported for different fish species of Bangladesh is presented in Table 4.

Table 4. Optimum incubation temperature of different fish species of Bangladesh

\begin{tabular}{llll}
\hline Name of the species & Scientific name & Temperature & Author \\
\hline Bata & Labeo bata & $27-31{ }^{\circ} \mathrm{C}$ & Miah et al., 2009 \\
\hline Sharputi & Barbonymus gonionotus & $26.6-27.5^{\circ} \mathrm{C}$ & Chakraborty et al., 2007 \\
\hline Mrigal & Cirrhinus cirrhosus & $25-30{ }^{\circ} \mathrm{C}$ & Chakrabatry \& Murty., 1972 \\
\hline Taki & Channa punctatus & $26-30{ }^{\circ} \mathrm{C}$ & Ramanathan et al., 1985 \\
\hline Local Koi & Anabas testudineus & $27-29{ }^{\circ} \mathrm{C}$ & Karim et al., 2012 \\
\hline Shing & Heteropneustes fossilis & $29{ }^{\circ} \mathrm{C}$ & Puvaneswari et al., 2009 \\
\hline Pabda & Ompok pabo & $29.3{ }^{\circ} \mathrm{C}$ & Sarma et al., 2012 \\
\hline Rita & Rita rira & $27-29{ }^{\circ} \mathrm{C}$ & Mollah et al., 2011 \\
\hline
\end{tabular}

\subsection{Post Hatching Development of the Hatched Larvae}

Post hatching development means the development of the larvae from the hatching till metamorphosis. The pattern of post hatching development of different species is different. Timing of development is also dependent on some environmental factors, like temperature of the water, available DO of the water, salinity etc. A typical chart on the development timing of different fish species reported for Bangladesh is given in the Table 5 .

Table 5. Timing of post hatching development of different fishes of Bangladesh

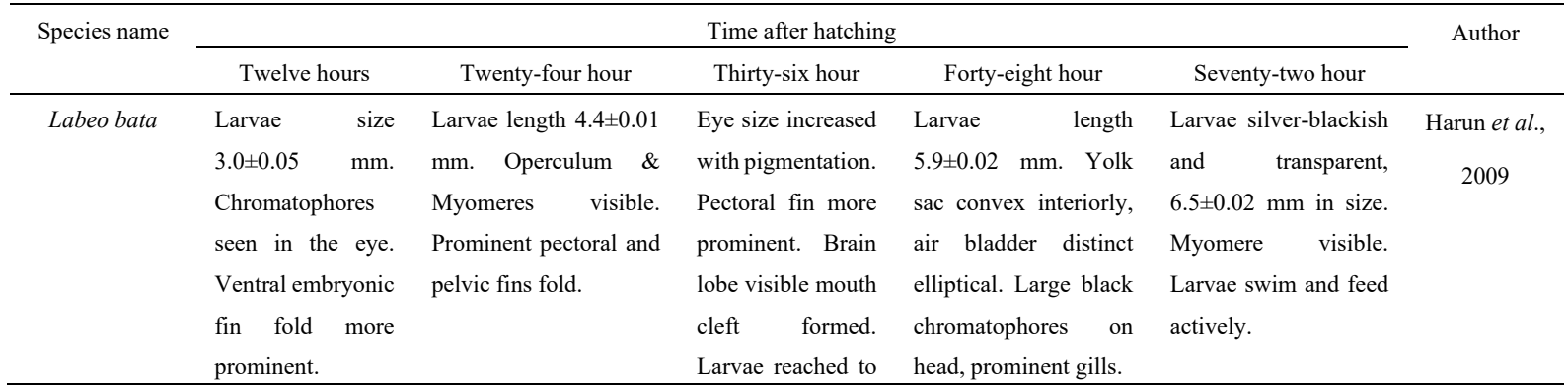




\begin{tabular}{|c|c|c|c|c|c|c|}
\hline & $\begin{array}{l}\text { Pectoral fin bud } \\
\text { appeared. }\end{array}$ & & $\begin{array}{l}5.5 \pm 0.05 \mathrm{~mm} \text { in } \\
\text { size. }\end{array}$ & & & \\
\hline Puntius sarana & $\begin{array}{l}\text { Larvae increased } \\
3.2 \pm 0.05 \mathrm{~mm} \text { in } \\
\text { size. Pectoral fin } \\
\text { bud appeared. } \\
\text { Melanophore } \\
\text { bands prominent } \\
\text { at the posterior } \\
\text { end of the body, } \\
\text { also appeared } \\
\text { above the eye and } \\
\text { around the yolk } \\
\text { sac. }\end{array}$ & $\begin{array}{l}\text { Larva length } 5.0 \pm 0.01 \\
\text { mm. Colour changed to } \\
\text { silvery-yellow. } \\
\text { Myomeres visible and } \\
\text { mouth cleft formed. }\end{array}$ & $\begin{array}{l}\text { Larve color } \\
\text { whitish-black. } \\
\text { Pectoral and } \\
\text { pelvic fin buds } \\
\text { found. Length of } \\
\text { the larva } 5.2 \pm \\
0.04 \mathrm{~mm} \text {. }\end{array}$ & $\begin{array}{l}\text { Air bladder distinct. A } \\
\text { few black } \\
\text { chromatophores found } \\
\text { in the area posterior to } \\
\text { the auditory and large } \\
\text { black chromatophores } \\
\text { observed on head. } \\
\text { Larvae size } 5.7 \pm 0.02 \\
\text { mm. }\end{array}$ & $\begin{array}{l}\text { Larval length } 5.8 \pm \\
0.01 \mathrm{~mm} \text {. Eyes fully } \\
\text { pigmented and } \\
\text { pectoral fin bud more } \\
\text { pronounced. }\end{array}$ & $\begin{array}{l}\text { Chakraborty } \\
\text { et al., } 2007\end{array}$ \\
\hline $\begin{array}{l}\text { Channa } \\
\text { striatus }\end{array}$ & $\begin{array}{l}\text { Length } 4.2 \mathrm{~mm} \text {, } \\
\text { Caudal fin begins } \\
\text { to separate and } \\
\text { pectoral fin buds. } \\
\text { Swim bladder } \\
\text { formed and heart } \\
\text { positioned in front } \\
\text { of the yolk. }\end{array}$ & & $\begin{array}{l}\text { Average length } \\
5.1 \mathrm{~mm} \text {. Pectoral } \\
\text { fin round shaped, } \\
\text { mouth formed, the } \\
\text { lower jaw less } \\
\text { developed, vent } \\
\text { formed. } \\
\text { Rudimentary gill } \\
\text { opening and pits } \\
\text { differentiate. } \\
\text { Thick band of } \\
\text { melanophore } \\
\text { observed. }\end{array}$ & $\begin{array}{l}\text { Average length } 5.4 \\
\text { mm. Pectoral fins } \\
\text { paddle shaped, mouth } \\
\text { formed with well- } \\
\text { developed jaw. Vent } \\
\text { and gill rudiments } \\
\text { clearly visible. Larvae } \\
\text { move at water surface } \\
\text { and feeding } \\
\text { exogenously. }\end{array}$ & & $\begin{array}{c}\text { Marimuthu } \\
\text { and Haniffa, } \\
2007\end{array}$ \\
\hline Rita rita. & $\begin{array}{l}\text { Larvae length } 2.2 \\
\text { mm. Yolk sac } \\
\text { partially reduced. } \\
\text { Alimentary canal } \\
\text { tube like. Eye spot } \\
\text { with a dark } \\
\text { pigmented area, } \\
\text { barbels found. }\end{array}$ & $\begin{array}{l}\text { Larvae length } 2.5 \mathrm{~mm} \text {. } \\
\text { Pectoral fin buds seen. } \\
\text { Pigmentation gradually } \\
\text { extended all over the } \\
\text { body, blood circulation } \\
\text { system fully developed }\end{array}$ & $\begin{array}{l}\text { Length } 2.8 \mathrm{~mm} \text {. } \\
\text { Distinct heart } \\
\text { visible, functioned } \\
\text { actively and } \\
\text { reddish blood seen } \\
\text { around the heart. } \\
\text { Dark pigmented } \\
\text { eyes and upper } \\
\text { and lower jaws } \\
\text { visible. } \\
\text { covered by the } \\
\text { operculum. Mouth } \\
\text { and anal pore } \\
\text { found with small } \\
\text { opening. }\end{array}$ & $\begin{array}{l}\text { Larvae length } 3.0 \mathrm{~mm} \text {. } \\
\text { Pectoral fin folds } \\
\text { became distinct and } \\
\text { the rudimentary rays } \\
\text { developed in the } \\
\text { caudal fin. Mouth } \\
\text { well-formed and } \\
\text { barbels became } \\
\text { elongated. Alimentary } \\
\text { tract straight and } \\
\text { distinct and a small } \\
\text { pouch like stomach } \\
\text { formed. Larvae } \\
\text { swimming smoothly } \\
\text { and feeding } \\
\text { exogenously at end of } \\
\text { this stage. }\end{array}$ & & $\begin{array}{l}\text { Mollah et } \\
\text { al., } 2011\end{array}$ \\
\hline $\begin{array}{c}\text { Macrognathus } \\
\text { aculeatus }\end{array}$ & $\begin{array}{l}\text { Larvae length } \\
2.8 \pm 0.05 \text { mm. } \\
\text { Pectoral fin bud } \\
\text { appeared. Large } \\
\text { number of } \\
\text { melanophores } \\
\text { appeared above } \\
\text { the eye and around } \\
\text { the yolk sac. }\end{array}$ & $\begin{array}{l}\text { Pectoral and pelvic fin } \\
\text { bud appeared. Air } \\
\text { bladder visible. Anus } \\
\text { became distinct. Larvae } \\
\text { increased to } 4.2 \pm 0.01 \\
\text { mm. }\end{array}$ & $\begin{array}{l}\text { Length of the larva } \\
5.2 \pm 0.04 \quad \text { mm. } \\
\text { Colour whitish- } \\
\text { black. } \\
\text { became whitish } \\
\text { black. }\end{array}$ & $\begin{array}{l}\text { Distinct air bladder } \\
\text { seen. Few black } \\
\text { chromatophores found } \\
\text { on the caudal fin. } \\
\text { Large black } \\
\text { chromatophores } \\
\text { observed on head. } \\
\text { Larvae increased to } \\
5.7 \pm 0.02 \mathrm{~mm} \text { in size }\end{array}$ & $\begin{array}{l}\text { Larvae length } \\
6.0 \pm 0.09 \mathrm{~mm} \text { and the } \\
\text { silver-blackish and } \\
\text { transparent in colour. } \\
\text { Eyes fully pigmented. } \\
\text { Dorsal and ventral fin } \\
\text { folds persistent. Larva } \\
\text { swims actively. }\end{array}$ & $\begin{array}{l}\text { Farid et al., } \\
2008\end{array}$ \\
\hline $\begin{array}{c}\text { Anabas } \\
\text { testudineus }\end{array}$ & & $\begin{array}{l}\text { Pectoral fins paddle } \\
\text { shaped and the } \\
\text { movements of fins were }\end{array}$ & & $\begin{array}{l}\text { Larva } 2.7 \mathrm{~mm} \text { in } \\
\text { length. Yolk sac } \\
\text { reduced to half. Brain }\end{array}$ & $\begin{array}{l}\text { Larvae length } 3.5 \mathrm{~mm} \\
\text { and mouth gap quite } \\
\text { large. Head broadened }\end{array}$ & $\begin{array}{l}\text { Karim et } \\
\text { al., } 2012\end{array}$ \\
\hline
\end{tabular}




\begin{tabular}{|c|c|c|c|c|c|}
\hline & $\begin{array}{l}\text { marked. Mouth } \\
\text { elliptical in shape and } \\
\text { inferior in position. Gill } \\
\text { appeared in the form of } \\
\text { comb and the supply of } \\
\text { yolk diminished } \\
\text { gradually. }\end{array}$ & & $\begin{array}{l}\text { formed completely and } \\
\text { continuous heart beat } \\
\text { visible. Mouth turned } \\
\text { in terminal position. }\end{array}$ & $\begin{array}{l}\text { than body and became } \\
\text { round in shape. Larva } \\
\text { started feeding at the } \\
\text { end of this period. }\end{array}$ & \\
\hline $\begin{array}{l}\text { Heteropneustes } \\
\text { fossilis }\end{array}$ & $\begin{array}{l}\text { Larvae length } 4.0 \pm 0.2 \\
\text { mm, reduced yolk sac } \\
\text { seen. Eyes dark } \\
\text { pigmented and } \\
\text { prominent. Pectoral fin } \\
\text { buds seen, jaws formed } \\
\text { and the alimentary tract } \\
\text { distinct. Heart visible } \\
\text { and the blood } \\
\text { circulatory system fully } \\
\text { functional. Barbells } \\
\text { appeared in the form of } \\
\text { tiny knobs. }\end{array}$ & $\begin{array}{l}\text { Length of larvae } \\
4.3 \pm 0.3 \text { mm. } \\
\text { Pectoral fin oval } \\
\text { shaped with a } \\
\text { membranous flap. } \\
\text { Mouth formed. } \\
\text { Rudimentary gill } \\
\text { openings and } \\
\text { olfactory pits } \\
\text { differentiated. The } \\
\text { yolk reserve } \\
\text { further } \\
\text { diminished. }\end{array}$ & $\begin{array}{l}\text { Larvae length } 4.6 \pm 0.2 \\
\text { mm. Barbells became } \\
\text { elongated and } \\
\text { prominent around the } \\
\text { mouth. Anal aperture } \\
\text { and opercula well- } \\
\text { formed and distinct. } \\
\text { Blood circulation } \\
\text { observed in the heart, } \\
\text { tail and opercula } \\
\text { region. }\end{array}$ & $\begin{array}{l}\text { Larvae length } 5.0 \pm 0.2 \\
\text { mm, brownish in } \\
\text { color. Mouth and anus } \\
\text { became fully } \\
\text { functional. Head } \\
\text { prominent and four } \\
\text { pairs of barbells } \\
\text { noticed. Pectoral fins } \\
\text { vascularized and the } \\
\text { caudal fin had } 5 \\
\text { rudimentary rays. The } \\
\text { yolk material } \\
\text { completely absorbed } \\
\text { and the larvae } \\
\text { exhibited vigorous } \\
\text { movements }\end{array}$ & $\begin{array}{c}\text { Nesa et al., } \\
2017\end{array}$ \\
\hline
\end{tabular}

\subsection{Factors That Influence Embryonic Development}

There are many factors that influences embryonic development of fish has been identified by different scientist. These factors may be categories into some category. These are internal factors like endocrine regulation of the fish or may be other external physico-chemical factors.

\subsubsection{Endocrine Regulation}

Study on endocrine regulation of the developing embryo is not well studied in Bangladeshi fishes except Shing and Koi. In case of Shing, Nesa et al., (2007) reported that a dorso-ventral unpaired fin, and some melanophores appeared on the head region, ventral side of the notochord and dorsal side of the body, probably by influence of some endocrine glands. Karim (2012) also reported some endocrine regulatory development of the Koi embryo, but didn't mentioned any special type of name of the gland. This two research clearly indicates that the development of early stages of the fishes are somehow regulated by the endocrine gland. But there is a lack of clear information that which gland is responsible for development of which organ. More research on this aspect is necessary in case of fish species of Bangladesh.

\subsubsection{Physico-Chemical Factors}

Embryonic stage is very crucial stage of a fish life. In this stage certain factors plays important role in the development of the embryo. There are many external factors that are responsible for regulation of the embryonic development of fish. These factors may be physical or may be chemical also. Temperature is the most vital factor that determines the proper development of the embryo. It has been proved as one of the major factors that regulate the development of the early embryonic stages of fish. Legendre \& Teugels, (1991) indicated that temperature have an influence on the development of the embryo. In a study in case of Labeo bata embryonic and larval development were reported optimum from $27{ }^{\circ} \mathrm{C}-31^{\circ} \mathrm{C}$ (Miah et al., 2009). Similar influence of temperature was observed in case of Shol, koi, indigenous Magur, Shing, Taki, pabda, Pangas in discrete study conducted by Ramanathan et al., 1985; Karim et al., 2012; Singh \& Vidyarthi, 1990; Benerji, 1975; Sarma et al., 2012; Ferosekhan et al., 2015, respectively. In a study conducted by Chattopadhyay and Chattoraj (2017), reported that gonadal development and spawning stops with the fall of temperature that happen with the approach of winter. This provides a straight indication that temperature along with photoperiod is the key controlling factor for maturation and spawning in fish. In case of spawning of fish such as carp and many other cyprinids, gonadal maturation begins in late winter or early spring. Therefore, it can easily be said that increasing temperature influence the maturation of gonad as well as influence the early developmental stages of fish which is also agreed by the result showed by Chakraborty et al., (2007) in case of Puntius sarana where the author found significant 
variation in the larval development in different temperature treatments. In case of Australian strain of Lates calcarifer the rate of embryonic development was positively correlated to the increase in incubation temperature and the thermal tolerance range for the Australian strain of $L$. calcarifer eggs was found to be $28-34{ }^{\circ} \mathrm{C}$ in a study conducted by Thepot and Jerry (2015). In case of Bangladeshi strain of $L$. calcarifer it may be more or less similar however it needs further research on Bangladeshi strain. In a study conducted by Das et al., (2006) reported highest hatching rate and least time for attaining each ontogenic stage at $31>33>26>36^{\circ} \mathrm{C}$ and were significantly different $(\mathrm{p}<0.05)$ in case of Labeo rohita. The lowest hatching percentage and maximum time duration for attaining a given ontogenic stage for $L$. rohita were observed at $36^{\circ} \mathrm{C}$ and also resulted in malformed embryos. Another important factor that affect the embryonic development of fishes is salinity. In case of L. rohita, Pillai et al., (2003) reported that survivability limit of $L$. rohita embryo in waters up to 8 ppt salinity but best embryonic development was obtained at 0 to $2 \mathrm{ppt}$.

Deprived of temperature and salinity, there are some other factors that may have influence on embryonic development of the fishes in Bangladesh. This are sound, light, chemical compounds of water such as DO, $\mathrm{pH}$, Alkalinity etc. (Rahman et al., 2011). But those factors are not well studied yet. Study on this factors that may influence the embryonic development is very important for Bangladeshi fish.

\section{Conclusion}

One of the major goals of fisheries biology is to inspect a fish stock and in terms of fisheries biology it is vital to know the embryonic and larval development. As these type of studies are essential to define the spawning periods and areas, to determine the chronological variations of the spawning period, to predict the mature stock of fish, to predict the rate of death of fish at the end of spawning period and to inspect the relation of the growth with its environment. In Bangladesh we need more research on the developmental biology of fishes, especially native or indigenous fish needs more concentration on this aspect.

\section{References}

Andrade, R. F., Bazzoli, N., Rizzo, E., \& Sato, Y. (2001). Continuous gametogenesis in the neotropical freshwater teleost, Bryconops affinis (Pisces: Characidae). Tissue and Cell, 33(5), 524-532. https://doi.org/10.1054/tice.2001.0206

Avidor-Reiss, T., Khire, A., Fishman, E. L., \& Jo, K. H. (2015). Atypical centrioles during sexual reproduction. Frontiers in cell and developmental biology, 25(22), 2956-2963. https://doi.org/10.3389/fcell.2015.00021

Banerji, S. R. (1975). Hypophysation and life history of Channa punctatus (Bloch). Journal of the Inland Fisheries Society of India.

Basak, S. K., Basak, B., Gupta, N., Haque, M. M., \& Amin, R. (2014). Embryonic and Larval Development of Silver Barb (Barbodes gonionotus) in a Mobile Hatchery under Laboratory Condition. European Scientific Journal, 10(10).

Chakraborty, B. K., Mirza, Z. A., Miah, M. I., Habib, M. A. B., \& Chakraborty, A. (2007). Reproductive cycle of the endangered sarpunti, Puntius sarana (Hamilton, 1822) in Bangladesh. Asian Fisheries Science, $20(1 / 2), 145$.

Chakraborty, R. D., \& Murty, D. S. (1972). Life history of Indian major carps Cirrhinus mrigala (Ham.), Catla catla (Ham.) and Labeo rohita (Ham.). Journal of Inland Fisheries Society, 4, 132-161.

Chattopadhyay, N. R., \& Chattoraj, S. (2017), A Review on the Reproduction and Development in Fish. Biomedical Journal of Scientific \& Technical Research, 1(6). doi: 10.26717/BJSTR.2017.01.000529

Ciechomski, J. D. (1964). Influence of some environmental factors upon the embryonic development of the Argentine anchovy (Engraulis anchoita. In Symposium on anchovies. Lake Arrowhead, California. November 22-24.

Coward, K., Campos, M. A., Larman, M., Hibbitt, O., McAndrew, B., Bromage, N., \& Parrington, J. (2003). Teleost fish spermatozoa contain a cytosolic protein factor that induces calcium release in sea urchin egg homogenates and triggers calcium oscillations when injected into mouse oocytes. Biochemical and biophysical research communications, 305(2), 299-304. https://doi.org/10.1016/S0006-291X(03)00753-8

Cox, L. J., Larman, M. G., Saunders, C. M., Hashimoto, K., Swann, K., \& Lai, F. A. (2002). Sperm phospholipase Czeta from humans and cynomolgus monkeys' triggers $\mathrm{Ca} 2+$ oscillations, activation and development of mouse oocytes. Reproduction, 124(5), 611-623.

Das, M., Tarafder, M. A. K., \& Pal, S. (2002). Early developmental stages of Nandus nandus (Ham.). Bangladesh 
Journal of Fisheries Research, 6(1), 11-18. aquaticcommons.org/id/eprint/17644

Das, T., Pal, A. K., Chakraborty, S. K., Manush, S. M., Dalvi, R. S., Sarma, K., \& Mukherjee, S. C. (2006). Thermal dependence of embryonic development and hatching rate in Labeo rohita (Hamilton, 1822). Aquaculture, 255(1-4), 536-541. https://doi.org/10.1016/j.aquaculture.2006.01.013

Eisler, R. (1957). Some effects of artificial light on salmon eggs and larvae. Transactions of the American Fisheries Society, 87(1), 151-162. https://doi.org/10.1577/1548-8659(1957)87[151:SEOALO]2.0.CO;2

Farid, S. M., Miah, M. I., Akter, M., Saha, D., \& Rahman, M. M. (2008). Embryonic and larval development of tara baim (Macrognathus aculeatus). Journal of Agroforestry and Environment, 2(2), 123-129. doi:http://dx.https://doi.org/10.12692/ijb/11.5.93-103

Ferosekhan, S., Sahoo, S. K., Giri, S. S., Saha, A., \& Paramanik, M. (2015). Embryonic and Larval Development of yellow tail catfish, pangasius pangasius. Journal of Aquaculture Research \& Development, 6(6),1-6. https://doi.org/10.4172/2155-9546.1000343

Forgacs, G., \& Newman, S A. (2005). Biological physics of the developing embryo. Cambridge University Press, 27.

Fukazawa, C., Santiago, C., Park, K. M., Deery, W. J., de la Torre Canny, S. G., Holterhoff, C. K., \& Wagner, D. S. (2010). poky/chuk/ikk1 is required for differentiation of the zebrafish embryonic epidermis. Developmental biology, 346(2), 272-283. https://doi.org/10.1016/j.ydbio.2010.07.037

Gilbert, S. (2010). Developmental Biology (9th ed.). Devbio Labortatory Vade Mecum. Sinauer Associates Inc., 243-247.

Hall, B. K. (2003). Evo-Devo: evolutionary developmental mechanisms. International Journal of Developmental Biology, 47(7-8), 491-495.

Hasan, M. R., Islam, M. S., Afroze, A., Bahdur, P., \& Akter, S. (2016). Captive breeding of Striped Spiny Eel, Mastacembelus pancalus (Hamilton, 1822) considering the various hormonal responses. International Journal of Fisheries and Aquatic Studies, 4(3), 07-11.

Hossain, Q. Z., Hossain, M. A., \& Parween, S. (2007). Breeding performance and nursery practices of Labeo bata (Hamilton-Buchanan, 1822). Scientific World, 5(5), 40-45. https://doi.org/10.3126/sw.v5i5.2654

IUCN. (2015). The IUCN Red List of Threatened Species in Bangladesh, 5.

Karim, M. R., Islam, M. T., Taslima, K., Fatema, M. K., \& Rashid, H. (2012). Ontogenic Development of Climbing

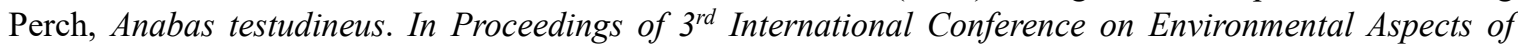
Bangladesh, 63-66.

Khan, H. (1943). On the breeding habit and development of an Indian Carp Cirrhinus mrigala (Hamilton). Proceedings of the Indian Academy of Science, 18B(1), 1-13.

Khan, M. H. K., \& Mollah, M. F. A. (2004). Further trials on induced breeding of Pangasius pangasius (Hamilton) in Bangladesh. Asian Fisheries Science, 17(1/2), 135-146.

Kinsey, W. H., Sharma, D., \& Kinsey, S. C. (2007). Fertilization and egg activation in fishes. In The Fish Oocyte. Springer, Dordrecht, 397-409. doi:10.1007/978-1-4020-6235-3_13

Kudo, S. (1982). The localization of concanavalin: A binding sites in the common carp egg. Zoological Magazine, 91(1), 39-47.

Kusa, M. (1953). On some properties of the cortical alveoli in the egg of the stickleback. Annotationes zoologicae japonenses, 26, 138-144.

Langeland, J., \& Kimmel, C. B. (1997). The embryology of fish. In S. F. Gilbert \& A. M. Raunio (Eds.), Embryology: Constructing the Organism (pp. 383-407). Sinauer Associates Inc, Sunderland MA, ISBN 087893-237-2.

Lee, K. W., Webb, S. E., \& Miller, A. L. (1999). A wave of free cytosolic calcium traverses zebrafish eggs on activation. Developmental biology, 214(1), 168-180. https://doi.org/10.1006/dbio.1999.9396

Lee, K. W., Webb, S. E., \& Miller, A. L. (2004). $\mathrm{Ca}^{2+}$ released via $\mathrm{IP}^{3}$ receptors is required for furrow deepening during cytokinesis in zebrafish embryos. International Journal of Developmental Biology, 47(6), 411-421.

Legendre, M., \& Teugels, G. G. (1991). Development and thermal tolerance of eggs in Heterobranchus longifilis, and comparison of larval developments of H. longifilis and Clarias gariepinus (Teleostei, Clariidae). Aquatic 
Living Resources, 4, 227-240.

Lubzens, E., Young, G., Bobe, J., \& Cerdà, J. (2010). Oogenesis in teleosts: how fish eggs are formed. General and comparative endocrinology, 165(3), 367-389. https://doi.org/10.1016/j.ygcen.2009.05.022

Marimuthu, K., \& Haniffa, M. A. (2007). Embryonic and larval development of the striped snakehead Channa striatus. Taiwania, 52(1), 84-92. doi:10.6165/tai.2007.52(1).84

Miah, M. I., Harun, M. S., Rahman, M. M., Haque, M. R., \& Hossain, M. A. (2009). Study on the embryonic and larval development of an endangered species of bata (Labeo bata). International Journal of Sustainable Crop Production, 4(1), 72-82.

Molla, M. F. A., Amin, M. R., Sarowar, M. N., \& Muhammadullah, M. (2008). Induced breeding of the riverine catfish Rita rita. Journal of the Bangladesh Agricultural University, 6(2), 361-366. https://doi.org/10.3329/jbau.v6i2.4835.

Mollah, M. F. A., Taslima, K., Rashid, H., Hossain, Z., Sarowar, M. N., \& Khan, M. R. K. (2011). Embryonic and larval development of critically endangered riverine catfish Rita rita. EurAsian Journal of BioSciences, 5, 110-118. doi:10.5053/ejobios.2011.5.0.13

Nakano, E. (1953). Respiration during maturation and at fertilization of fish eggs. Embryologia, 2(2), 21-31. https://doi.org/10.1111/j.1440-169X.1953.tb00049.x

Nesa, N. U., Ahmed, S., \& Rahman, S. M. (2017). Breeding Performance, Embryonic and Larval Development of Stinging Catfish, Heteropneustes fossilis in Bangladesh. Journal of Environmental Science and Natural Resources, 10(1), 141-148. https://doi.org/10.3329/jesnr.v10i1.34708

Pal, S., Rashid, H., Tarafder, M. A. K., Narejo, N. T., \& Das, M. (2003). First Record of Artificial Spawning of Nandus nandus (Hamiltom) in Bangladesh Using Carp Pituitary Gland: An Endangered Species Bred in Captivity. Pakistan Journal of Biological Sciences, 6, 1621-1625.

Pillai, D., Jose, S., Mohan, M. V., \& Joseph, A. (2003). Effect of salinity on growth and survival of rohu. Labeo rohita (Ham.) under laboratory and field conditions. Fishery Technology, 40(2), 91-94.

Purkayastha, S., Sarma, S., Sarkar, U. K., Lakra, W., Gupta, S., \& Biswas, S. P. (2012). Captive breeding of endangered Ompok pabda with Ovatide. Journal of Applied Aquaculture, 24(1), 42-48. https://doi.org/10.1080/10454438.2012.652027

Puvaneswari, S., Marimuthu, K., Karuppasamy, R., \& Haniffa, M. A. (2009). Early embryonic and larval development of Indian catfish, Heteropneustes fossilis. EurAsian Journal of BioSciences, 3, 84-96. https://doi.org/10.5053/ejobios.2009.3.0.12

Rahman, M. M., Miah, M. I., Taher, M. A., \& Hasan, M. M. (2009). Embryonic and larval development of guchibaim, Mastacembelus pancalus (Hamilton). Journal of Bangladesh Agricultural University, 7(1), 193204. https://doi.org/10.3329/jbau.v7i1.4984

Rahman, M. R., Rahman, M. A., Khan, M. N., \& Hussain, M. G. (2004). Observation on the embryonic and larval development of silurid catfish, gulsha (Mystus cavasius Ham.). Pakistan Journal of Biological Sciences, 7(6), 1070-1075.

Rahman, S. M., Habib, M. A., Hossain, Q. Z., Siddiqui, M. N., Rahman, M. M., \& Ahsan, M. N. (2011). Embryonic development of Clarias batrachus under the influence of aeration and water flow. Ecoprint: An International Journal of Ecology, 18, 25-31. https://doi.org/10.3126/eco.v18i0.9395

Raizada, S., Lal, K. K., Sarkar, U. K., Varshney, P. K., Sahu, V., Yadav, K. C., \& Jena, J. K. (2013). Captive breeding and embryonic development of butter catfish (Ompok bimaculatus, Bloch 1794), a threatened fish of Indian sub-continent in Northern India. Proceedings of the National Academy of Sciences, India Section B: Biological Sciences, 83(3), 333-339. doi:10.1007/s40011-013-0156-z

Ramanathan, N., Natarajan, P., \& Sukumran, N. (1985). Studies on the induced spawning and larval rearing of a freshwater catfish, Mystus punctatus (Jerdon). Proceedings: Animal Sciences, 94(4), 389-398. doi:10.1007/BF03186346

Roy, N. C., Chowdhury, S. K., \& Das, S. K. (2016). Observation of hapa breeding technique of striped snakehead, Channa striatus (Bloch, 1793) under captive condition. International Journal of Fisheries and Aquatic Studies, 4(5), 413-417.

Sarma, D., Das, J., Dutta, A., \& Goswami, U. (2012). Early embryonic and larval development of Ompok pabo 
with notes on its nursery rearing. European Journal of Experimental Biology, 2(1), 253-260.

Saunders, C. M., Larman, M. G., Parrington, J., Cox, L. J., Royse, J., Blayney, L. M., \& Lai, F. A. (2002). A spermspecific trigger of Ca2+ oscillations in eggs and embryo development. Development, 129(15), 3533-3544.

Sayeed, M. A., Akter, S., Paul, A. K., Ahashan, M. R., Miah, M. M. H., \& Hossain, M. A. R. (2009). Development of artificial breeding technique of gutum, Lepidocephalichthys guntea (Hamilton, 1822) using carp pituitary gland. Journal of Agroforestry and Environment, 3(1), 195-197.

Sharma, S., Hanukoglu, A., \& Hanukoglu, I. (2018). Localization of epithelial sodium channel (ENaC) and CFTR in the germinal epithelium of the testis, Sertoli cells, and spermatozoa. Journal of Molecular Histology, 49(2), 195-208. https://doi.org/10.1007/s10735-018-9759-2

Singh, K. M. P., \& Vidyarthi, S. (1990). Induced breeding, embryonic and larval development in Heteropneustes fossilis (Bloch) in the agro-climatic conditions of Maharashtra. Journal of the Indian Fisheries Association, 20, 15-19. http://aquaticcommons.org/id/eprint/15921

Sperber, G. H. (1995). Developmental biology, By Scott F. Gilbert, Sinauer Associates, Inc., Sunderland, Massachusetts, and WH Freeman, UK, 1994, pp29.95. American Journal of Medical Genetics, 57(4), 642642. https://doi.org/10.1002/ajmg.1320570429

Thepot, V., \& Jerry, D. R. (2015). The effect of temperature on the embryonic development of barramundi, the Australian strain of Lates calcarifer (Bloch) using current hatchery practices. Aquaculture Reports, 2, $132-$ 138. https://doi.org/10.1016/j.aqrep.2015.09.002

Trinkaus, J. P. (1984). Cells into organs: the forces that shape the embryo. http://hdl.handle.net/10822/801406

Tumbahangfe, J., Subba, B. R., \& Jha, S. K. (2014). Embryonic Development of Bhakur, Catla catla Hamilton 1822 (Cyprinidae). Our Nature, 12(1), 49-53. https://doi.org/10.3126/on.v12i1.12257

Verreth, J. A., Torreele, E., Spazier., E, Van der Sluiszen, A., Rombout, J. H., Booms, R., \& Segner, H. (1992). The development of a functional digestive system in the African catfish Clarias gariepinus (Burchell). Journal of the World Aquaculture Society, 23(4), 286-298. https://doi.org/10.1111/j.1749-7345.1992.tb00792.x

Warga, R. M., \& Kimmel, C. B. (1990). Cell movements during epiboly and gastrulation in zebrafish. Development 108(4), 569-580.

\section{Copyrights}

Copyright for this article is retained by the author(s), with first publication rights granted to the journal.

This is an open-access article distributed under the terms and conditions of the Creative Commons Attribution license (http://creativecommons.org/licenses/by/4.0/). 